\title{
PERANAN INOVASI PRODUK DAN LAYANAN DALAM MENINGKATKAN DAYA TARIK NASABAH MENABUNG DI BMT MU'ALLIMIN
}

\section{ROLE OF PRODUCT INNOVATION AND CUSTOMERS SERVICE TO INCREASE SAVING ATTRACTION IN BMT MU'ALLIMIN}

\author{
S. A. Firdaus ${ }^{1 a}$ \\ 1a Program Studi Ekonomi Islam Fakultas Ekonomi Islam Universitas Djuanda, Jl. Tol Ciawi No. 1, \\ Kotak Pos 35 Bogor 16720
}

\begin{abstract}
This study aims to determine the role of innovation products and innovation services customers to increase the attractiveness of customers saving in BMT Mu'allimin. Type of research using quantitative descriptive data collection system with questionnaires and interviews. The study population all customers BMT Mu'allimin with sample set through a formula slovin much as 128 respondents. Data analysis techniques through descriptive analysis techniques and analyzed using frequency distribution of reactive. Results of research of this title is innovation of products and services customers BMT Mu'allimin quite a role in increasing the attractiveness of customers to save, especially innovative services owned BMT Mu'allimin that is EDC and SMS Banking.
\end{abstract}

Keywords: Product Innovation, Innovation Services, Interest Savings.

\begin{abstract}
ABSTRAK
Penelitian ini bertujuan untuk mengetahui peran inovasi produk dan inovasi layanan dalam meningkatkan daya tarik nasabah menabung di BMT Mu'allimin. Jenis penelitiannya menggunakan deskriptif kuantitatif disertai sistem pengumpulan data kuesioner dan wawancara. Populasi penelitian seluruh nasabah BMT Mu'allimin dengan sampel penelitian yang ditetapkan melalui rumus slovin sebanyak 128 responden. Teknik analisis data melalui teknik analisis deskriptif dan dianalisa menggunakan distribusi frekuensi relatif. Hasil penelitian dari judul ini ialah inovasi produk dan inovasi layanan BMT Mu'allimin cukup berperan dalam meningkatkan daya tarik nasabah untuk menabung, terutama inovasi layanan yang dimiliki BMT Mu'allimin yaitu mesin EDC dan SMS Banking.
\end{abstract}

Kata kunci: Inovasi Produk, Inovasi Layanan, Minat Menabung.

Firdaus, Siti Anisa. 2017. Peran Inovasi Produk Dan Layanan Dalam Meningkatkan Daya Tarik Nasabah Menabung di BMT Mu'allimin. Jurnal Syarikah 3 (2): 419 - 435.

\section{PENDAHULUAN}

LKMS kini terus tumbuh dengan signifikan, kondisi tersebut diperkuat dengan data pertumbuhan aset LKMS tahun 2015 akhir berada pada angka 27 miliar, kemudian mengalami peningkatan signifikan senilai 63 miliar pada November 2016 (Otoritas Jasa Keuangan, 2016). Salah satu wujud dari LKMS adalah Baitul Maal wat Tamwil (BMT). BMT adalah LKMS yang memiliki kegiatan utama yaitu funding (penghimpunan) dan financing (pembiayaan) dana dari dan kepada 
masyarakat untuk tujuan sosial dan niaga (Damayanti dan Herianingrum, 2014: 197). Dengan kegiatan tersebut, BMT dapat melayani kebutuhan transaksi dan mendukung masyarakat dalam meningkatkan usaha mereka melalui penyaluran pembiayaan, khususnya masyarakat pada tingkat menengah kebawah. Akibatnya, persaingan antara satu BMT dengan BMT lainnya kini semakin ketat untuk dapat membuat masyarakat tertarik membuka tabungan di BMT. Dengan demikian, sekarang ini BMT pada umumnya melakukan beraneka macam cara dalam menarik dan membuat masyarakat berminat mengamankan uang di BMT mereka masing-masing, satu diantara banyak upaya yang dijalankan yaitu melalui inovasi layanan dan produk.

Inovasi produk atau inovasi layanan umumnya diadakan setiap institusi dan organisasi termasuk BMT sebagai cara untuk meningkatkan atau mempertahankan pelanggan. Dalam sebuah BMT, inovasi adalah satu cara dari banyak metode yang dapat meningkatkan minat masyarakat untuk menabung atau mempertahankan nasabah untuk tetap menabung. Faktor yang memicu ketertarikan nasabah agar bersedia menabung di BMT tidak hanya dari inovasi produk, tetapi dari faktor yang lain juga. Namun nyatanya yang umum dilakukan BMT sekarang ini yaitu melakukan inovasi dari sisi produk dan pelayanan, maka dalam karya ilmiah ini peneliti akan memaparkan peran inovasi produk serta inovasi layanan dalam meningkatkan ketertarikan nasabah membuka tabungan di BMT Mu'allimin.

\section{MATERI DAN METODE}

Inovasi produk adalah kreasi produk baru berupa jasa atau barang dimana penemuannya dilakukan dalam semua sisi termasuk kegunaan / fungsi sebagai upaya untuk memuaskan dan mempertahankan konsumen atau pelanggan (Swityastuti dan Sutrisno, 2014, Sukarmen, 2013). Produk dikatakan sebagai inovasi tidak cukup hanya sekedar berbeda dari yang lain, tetapi produk dapat dikatakan sebagai inovasi dengan merujuk pada karakteristik yang merupakan landasan dari inovasi. Rogers (1983) menjelaskan karakteristik inovasi berikut (Juniarti, 2015: 49): pertama, Inovasi memiliki benefit relatif (relative advantage), yaitu inovasi baru memberikan profit relatif dari inovasi sebelumnya. Keuntungan tersebut bukan hanya seputar ekonomi atau keuangan saja, melainkan keuntungan terkait bertambahnya pengetahuan, pemenuhan kebutuhan, dan aspek lainnya. Kedua, Kesesuaian (compatibility), yaitu inovasi yang dipromosikan memiliki kesesuaian dengan kepentingan masyarakat, pengalaman sebelumnya, dan nilai, norma, serta adat setempat. Ketiga, Kerumitan (complexity), yaitu inovasi dinilai kerumitannya oleh individu. Inovasi yang sederhana dipahami serta disampaikan. Keempat, Mudah diuji coba (trability), yaitu suatu inovasi akan mudah diadopsi apabila bisa diuji lebih dahulu. Kelima, Mudah diamati (observability), ialah melihat secara langsung merupakan kemudahan ketika mengadopsi suatu inovasi. Dengan berbagai karakteristik yang diperhatikan sedemikian rupa dalam melakukan inovasi, inovasi tetap saja adalah satu hal baru, sehingga memungkinkan timbulnya risiko. Menurut Gatignon \& Robertson (1991) terdapat beberapa risiko terhadap adopsi sebuah inovasi, yaitu (Uliana, 2012: 24): Uncertainty Risk, yang menunjuk pada buruknya standarisasi untuk mengevaluasi inovasi; Performance Risk, yang melihat pada apakah inovasi akan memiliki kinerja yang sinkron dengan harapan; Social Risk, yang menyatakan kerugian pada status sosial apabila melakukan kesalahan pada saat melakukan inovasi atau mengambil/adopsi langkah untuk berinovasi; dan Physical Risk, yang meninjau pada risiko bahaya secara fisik kepada yang melakukan inovasi atau menerima hasil inovasi. 
Inovasi produk tidak semata-mata melahirkan produk baru tetapi menambah atribut produk semacam fitur, kualitas dan desain produk termasuk dalam bagian inovasi. Karena kondisi saat ini apabila terdapat beberapa jasa serta barang yang hendak dikonsumsi, pertimbangan pertama yang dilakukan konsumen adalah membandingkan pada tiap-tiap produk dari sisi nilai dan atribut produk (Suatma, 2013: 19). Mungkin bagi perusahaan hal tersebut belum termasuk inovasi, tetapi bagi konsumen hal tersebut berbeda sehingga masuk kedalam inovasi. Banyak pandangan yang mengukur inovasi dari sisi yang berbeda-beda. Daneels \& Kleinscmidt (2001) dalam penelitiannya, mengukur tingkat inovasi berdasarkan tingkat inovasi produk yang dihasilkan (product innovativeness). Dimana terdapat dua dimensi inovasi produk (product innovativeness) (Uliana, 2012: 25). Pertama, Inovasi produk dari perspektif perusahaan (product innovativeness from firm's perspective), diukur berdasarkan sub-sub dimensi yang lazim disebut dengan familiarity, fit, technology dan marketing. Inovasi produk dari perspektif perusahaan (product innovativeness from firm's perspective) dapat dilihat ketika perusahaan ingin mengembangkan atau meluncurkan produk baru. Perusahaan diperlukan melahirkan sebuah produk berdasarkan sasaran pasar yang mereka bidik dengan melihat aspek-aspek berasaskan standar yang perusahaan miliki, sehingga terciptanya inovasi produk baru setara dengan sasaran pasar dan positioning yang direncanakan oleh perusahaan. Kedua, Inovasi produk dari perspektif konsumen (product innovativeness from costumer's perspective), diukur kedalam tiga sub dimensi yaitu: (a) Innovation attributes yang bertumpu pada komponen-komponen yang mempengaruhi cepat atau lambatnya sebuah inovasi diadopsi; (b) Adoption risk yaitu melihat risiko-risiko yang menjadi pertimbangan dalam adopsi inovasi; (c) behavior change menunjuk pada besar atau tidaknya perubahan perilaku dari adopter saat mengadopsi sebuah inovasi.

Menurut Ferrell terdapat beberapa indikator dalam inovasi produk diantaranya adalah perluasan lini, produk baru dan produk benar-benar baru (Firdausi, 2016: 30). Indikator tersebut dijadikan tumpuan setiap institusi/organisasi yang hendak mengadakan inovasi produk, termasuk yang berjalan dibidang keuangan seperti BMT. Namun inovasi produk BMT yang diaplikasikan pada umumnya belum memenuhi indikator produk benar-benar baru, sehingga fokus penelitiannnya pada indikator perluasan lini serta produk baru saja. Dengan demikian indikator tersebut menjadi bagian dalam pemaparan terkait peran inovasi produk meningkatkan daya tarik nasabah membuka tabungan di BMT Mu'allimin.

Selanjutnya yaitu inovasi layanan atau yang umum disebut dengan jasa. Layanan merupakan tiap aktivitas atau tindakan yang ditawarakan satu pihak pada lain pihak yang sebetulnya tak berwujud serta tidak mengakibatkan kepemilikan apapun, sedangkan Inovasi layanan (service innovation) ialah pembaharuan atau perbaikan secara signifikan pada konsep layanan yang diaplikasikan dengan praktis (Mardikawati dan Farida, 2013; Daud, 2016). Jika diungkapkan wujudnya berupa pembaharuan saluran interaksi konsumen, sistem distribusi dan konsep teknologi atau kombinasinya. Selain itu, menurut Cheng and Krumwiede mengungkapkan bahwa inovasi layanan dapat berbentuk inovasi inkremental dan inovasi radikal. Inovasi inkremental berkenaan dengan kebutuhan riil konsumen, sedangkan inovasi radikal memperlihatkan adanya perubahan dasar pada layanan baru serta memberi manfaat layanan yang nyata (Daud, 2016: 69).

\section{Jenis Penelitian}

Jenis penelitiannya ialah deskriptif kuantitatif. Penelitian kuantitatif juga digambarkan seperti desain penelitian berdasarkan paham positivisme, dipakai 
dalam meneliti sampel atau populasi tertentu, pengumpulan data memakai instrumen penelitian, sifat dari analisis datanya yaitu kuantitatif / statistik, dengan maksud menguji coba hipotesis yang ditetapkan (Sugiyono, 2013: 11). Penelitian deskriptif kuantitatif ialah penelitian yang memberikan deskripsi suatu keadaan dengan jelas tanpa perlu perlakuan obyek yang diteliti. Jenis penelitian deskriptif kuantitatif pada studi ini maksudnya yaitu menyampaikan penjelasan secara terstruktur mengenai peran inovasi produk dengan tujuan meningkatkan ketertarikan nasabah membuka rekening tabungan di BMT.

\section{Populasi dan Sampel}

Lingkup generalisasi yang meliputi subyek/obyek yang punya kualitas dan juga karakteristik tersendiri yang ditetapkan pihak peneliti untuk dipahami dan setelah itu ditarik kesimpulannya disebut populasi (Sugiyono, 2013: 119). Penetapan populasi dari peneiltian ini adalah seluruh nasabah BMT Mu'allimin. Sedangkan sampel merupakan anggota dari kuantitas dan ciri-ciri yang termasuk kedalam populasi tersebut (Sugiyono, 2013: 120). Penentuan sampel studi ini yaitu nasabah BMT Mu'allimin yang jadi bagian dari populasi dengan jumlah 128 sampel.

\section{Teknik Sampling}

Teknik Simple Random Sampling yaitu sistem penarikan sampel dalam studi ini. Simple Random Sampling ialah pengambilan sampelnya mencampur subyek-subyek didalam populasi sehingga semua subyek dianggap sama (Abdullah, 2015: 234).

Adapun besaran sampel ditetapkan dengan menghitung statistik melalui Rumus Slovin. Rumus Slovin yaitu memasukan aspek kerenggangan ketidaktelitian disebabkan kesalahan dalam menarik sampel yang masih bisa ditoleransi. Rumus Slovin berguna menetapkan ukuran sampel dari populasi yang diketahui jumlahnya yaitu sebanyak 188 orang. Penetapan tingkat presisi dalam penentuan sampel adalah 5\%. Adapun rumusnya ialah sebagai berikut (Abdullah, 2015: 237):

$\mathrm{n}=\frac{\mathrm{N}}{1+\mathrm{Ne}^{2}}$

Keterangan:

$\mathrm{n}=$ ukuran sampel

$\mathrm{N} \quad=$ ukuran populasi

$\mathrm{e}=$ toleransi ketidaktelitian dalam persen (\%).

Berdasarkan Rumus Slovin, maka besarnya penarikan jumlah sampel penelitian adalah:

$\mathrm{n}=\frac{\mathrm{N}}{1+\mathrm{Ne}^{2}}$
$\mathrm{n}=\frac{188}{1+188(0,05)^{2}}=127,89$ digenapkan 128.

Hasil perhitungan dari rumus tersebut menegaskan bahwa sampel penelitian ini yaitu sebanyak 128 sampel.

\section{Sumber Data}

Sumber-sumber data dalam studi ini mencakup data primer serta data sekunder. 1. Data primer yaitu data didapat dari sumber utama baik perseorangan atau individu, semisal wawancara atau hasil pengisian kuesioner (Abdullah, 2015: 246). Untuk penelitian ini data primer dihasilkan melalui pembagian kuesioner pada nasabah serta wawancara.

2. Data sekunder ialah data primer hasil proses lebih lanjut yang disiapkan oleh bagian penghimpun data primer atau pihak lain, biasanya ditampilkan berupa tabel serta diagram (Abdullah, 2015: 247). Data sekunder penelitian ilmiah ini didapat dari output data primer, dokumentasi, jurnal atau referensi lainnya yang bertautan dengan penelitian ilmiah ini.

\section{Teknik Pengumpulan Data}

Tata cara mengumpulkan data dilaksanakan melalui pembagian kuesioner dan juga wawancara.

1. Kuesioner (angket) adalah teknik mengumpulkan data melalui penyebaran kumpulan pertanyaan kepada responden, dengan maksud 
mereka akan memberikan respon dari kumpulan pertanyaan peneliti (Abdullah, 2015:248). Teknik penyebaran kuesioner dilaksanakan dengan menyerahkan pertanyaanpertanyaan kepada nasabah BMT Mu'allimin untuk dijawab dengan pilihan jawaban yang telah disediakan.

2. Wawancara merupakan satu diantara berbagai cara dalam menghimpun data yang dijalankan secara langsung (tatap muka) antar peneliti dengan responden (Abdullah, 2015: 250). Wawancara dilakukan pada saat penyebaran kuesioner dengan cara menemui responden atau nasabah BMT Mu'allimin secara langsung. Dilakukannya wawancara ini sebagai teknik untuk memperkuat atau memperdalam data.

\section{Teknik Analisis Data}

Karya ilmiah ini menggunakan teknik yang dijalankan melalui tahap-tahap berikut:

\section{Uji Reliabilitas dan Uji Validitas}

Uji reliabilitas dimanfaatkan untuk memperkirakan suatu nilai yang akan menunjukan konsistensi instrumen pengukur dalam mengukur tanda-tanda yang sama, setiap instrumen pengukur harusnya mempunyai kemampuan membuahkan hasil pengukuran tetap (Abdullah, 2015: 260). Pengujian dilaksanakan untuk tujuan agar dapat memastikan alat penelitian yang dikenakan yaitu instrumen yang stabil atau konsisten, sehingga jika digunakan berkali-kali tetap menghasilkan data yang serupa (Sofiah dan Trihantana, 2016: 239)

Uji validitas digunakan untuk menunjukkan sejauh mana suatu alat pengukur itu menghitung apa yang diukur (Abdullah, 2015: 258). Artinya uji validitas digunakan dalam mengukur kelayakan kuesioner yang selanjutnya dimanfaatkan untuk penelitian.

2. Skala Likert

Skala Likert ialah skala yang memberikan kegunaan dalam mengukur sikap, anggapan dan persepsi individu atau sekumpulan orang perihal fenomena sosial (Riduwan dan Sunarto, 2014: 20). Melalui penggunaan skala likert, permulaan pengukuran variabel dijelaskan dari variabel menjadi parameter variabel yang bisa diukur untuk membantu memudahkan responden dalam menjawab pertanyaan/pernyataan (Wadah, 2016, Amrillah dan Brawijaya, 2016). Skala likert secara umum menggunakan empat tingkat preferensi, namun ada yang menggunakan lima tingkat preferensi dengan skor masing-masing yang sudah ditentukan seperti tabel 1. (Sugiyono, 2013: 136).

\section{Tabel 1. Nilai Jawaban Pernyataan}

\begin{tabular}{|c|l|}
\hline Nilai & \multicolumn{1}{|c|}{ Jawaban } \\
\hline 5 & Sangat Setuju \\
4 & Setuju \\
3 & Kurang Setuju \\
2 & Tidak Setuju \\
1 & Sangat Tidak Setuju \\
\hline \multicolumn{2}{|l}{ Sumber: Sugiyono 2013 } \\
\hline
\end{tabular}

\section{Analisis Data}

Analisis deskriptif dan distribusi frekuensi relatif ialah analisis data yang diperlukan dalam karya ilmiah ini. Deskriptif analisis yaitu menggambarkan sesuai dengan keadaan yang kemudian dianalisis. Distribusi frekuensi relatif digunakan untuk mempermudah dalam menganalisis data. Distribusi Frekuensi Relatif adalah distribusi frekuensi dimana frekuensinya diperlihatkan dengan bilangan-bilangan tertentu yang berupa persentase dan total keseluruhan frekuensinya sama dengan 1 atau $100 \%$ (Setyawan, 2013: 7).

Bentuk ratio :

Bentuk Persentase :

$$
f_{i} \text { relatif }=\frac{f_{i}}{\sum f}
$$

$$
f_{i} \text { relatif }=\frac{f_{i}}{\sum f} \times 100
$$




\section{HASIL DAN PEMBAHASAN}

\section{Gambaran Umum Objek Penelitian}

BMT Mu'allimin sudah berdiri dan resmi berjalan dari tanggal 13 Oktober 2016. Sejarah berdirinya BMT Mu'allimin diawali dengan adanya gagasan dari dosendosen Fakultas Ekonomi Islam Universitas Djuanda Bogor untuk membangun sebuah BMT. Kata mu'allimin pada nama BMT ini asalnya dari istilah arab berarti pengajar atau guru. Karena gagasan pendiriannya berasal dari para dosen dan hampir seluruh pengurus BMT Mu'allimin adalah para dosen juga, akhirnya dinamakan BMT Mu'allimin. Adapun tujuan para pengurus mendirikan BMT Mu'allimin yaitu ingin membangun atau mengelola BMT yang praktiknya benar-benar murni berdasarkan pada hukum-hukum syariah dengan harapan kedepannya BMT Mu'allimin mampu menjadi contoh bagi BMT yang lain khususnya wilayah Bogor dan umumnya bagi seluruh BMT di Indonesia. Selain itu, tujuan penting lainnya dari pembangunan BMT Mu'allimin adalah dapat mendukung masyarakat dalam menumbuhkan usaha mikro atau kebutuhan transaksi lainnya, serta dapat menjadi sarana penyerap lulusan-lulusan yang dasar pendidikannya merupakan ekonomi islam sebagai SDM berkualitas dan berguna bagi masa depan sistem keuangan Islam. Sekarang ini BMT Mu'allimin memiliki kantor yang bertempat di Jl.Aria Surialaga No.26 Pasirkuda, Bogor Barat, Kota Bogor.

\section{Visi dan Misi BMT Mu'allimin}

Visi

Menjadi BMT yang profesional, produktif, mandiri dan memberikan keberkahan bagi ummat.

Misi

a. Mewujudkan manajemen BMT yang sehat dan transparan

b. Mewujudkan BMT yang dapat mendorong pertumbuhan usaha mikro dari kecil

c. Menjadikan nasabah BMT yang berdikari dan mandiri d. Mewujudkan keberkahan aktivitas ekonomi nasabah BMT.

\section{Produk dan Layanan Jasa BMT Mu'allimin}

1. Produk Simpanan

a. Simpanan Wadiah

Simpanan wadiah merupakan simpanan sukarela menggunakan akad wadi'ah yad-dhamanah yang penyetoran atau penarikannya dapat dilayani kapan saja oleh anggota. Setoran perdana untuk produk simpanan wadiah adalah Rp. 100.000,--

b. Simpanan Pendidikan

Simpanan pendidikan merupakan simpanan menggunakan akad sama dengan simpanan wadiah namun penarikannya hanya bisa dicairkan untuk kepentingan biaya pendidikan saja. Simpanan pendidikan disediakan untuk siswa SMA, SMP, SD, Mahasiswa dan Santri. Dana yang harus masuk pertama kali untuk simpanan pendidikan adalah Rp. 15.000,-. Dalam simpanan pendidikan, BMT Mu'allimin dapat membagikan bonus kepada anggota sebagai bentuk penghargaan atas pemanfaatan dana tersebut oleh BMT Mu'allimin.

c. Simpanan Qurban

Simpanan qurban ialah simpanan berakad wadiah yang sistem penarikannya bisa dilakukan ketika menjelang perayaan qurban saja. Setoran perdana untuk simpanan qurban adalah Rp. 150.000,-. Dalam simpanan qurban, BMT Mu'allimin dapat memberikan imbalan semacam bonus kepada anggota sebagai bentuk apresiasi atas pemanfaatan dana tersebut oleh BMT Mu'allimin.

d. Simpanan Idul Fitri

Simpanan ini merupakan titipan berupa tabungan dengan penggunaan akad sama seperti dalam simpanan qurban dan simpanan lain yang sistem penarikannya hanya dilayani ketika menjelang perayaan Idul Fitri. 
Uang pertama yang harus masuk yaitu Rp. 100.000,-. Dalam tabungan idul fitri, BMT Mu'allimin mampu memberikan kompensasi berupa bonus untuk anggota sebagai bentuk apresiasi atas pemanfaatan dana tersebut oleh BMT Mu'allimin.

e. Simpanan Walimah

Simpanan walimah merupakan simpanan berencana memakai akad wadiah yad-dhamanah yang disediakan bagi setiap anggota yang ingin memiliki persiapan untuk walimah. Setoran perdana untuk simpanan walimah yaitu Rp. 100.000,--

f. Simpanan Rihlah

Simpanan rihlah merupakan simpanan berencana memakai akad wadiah yad-dhamanah yang disediakan bagi setiap anggota yang memiliki niat untuk melakukan rihlah. Setoran yang masuk pertama untuk simpanan rihlah adalah Rp. 15.000,-.

g. Deposito (Simpanan Berjangka)

BMT Mu'allimin menyediakan simpanan berjangka berupa deposito mudharabah. Deposito mudharabah merupakan simpanan berjangka dengan penggunaan akad mudharabah mutlaqah tentunya dijalankan berlandaskan asas pembagian hasil bersama anggota dan diberikan setiap bulan. Adapun jangka waktunya mulai dari 3, 6, 9 atau 12 bulan. Setoran perdana untuk simpanan berjangka adalah Rp. 2.000.000,-.

h. Simpanan Haji dan Umroh

1) Haji

Simpanan haji merupakan simpanan dengan akad wadiah yad-dhamanah. Setoran perbulan untuk simpanan haji adalah $\mathrm{Rp}$. 1.250.000,-. Adapun kurun waktu penyetorannya selama 36 bulan. Dalam simpanan haji, BMT Mu'allimin dapat memberikan kompensasi seperti bonus kepada anggota atas pemanfaatan dana tersebut oleh BMT Mu'allimin.

2) Umroh Promo

Simpanan umroh promo merupakan tabungan yang memakai akad wadiah yaddhamanah. Setoran perbulan untuk simpanan umroh promo adalah Rp. 1.000.000,-. Adapun batasan waktu setorannya adalah 24 bulan. Dalam simpanan umroh promo, BMT Mu'allimin dapat berbagi bonus kepada anggota sebagai bentuk penghargaan atas penggunaan dana tersebut oleh BMT Mu'allimin.

3) Umroh Reguler

Simpanan umroh reguler merupakan titipan berupa simpanan dengan akad wadiah yad-dhamanah. Setoran perbulan untuk simpanan umroh reguler adalah Rp. 1.250.000,-. Adapun tenggang waktu angsurannya yaitu selama 24 bulan. Dalam simpanan umroh reguler, BMT Mu'allimin dapat memberikan balasan berupa bonus pada anggota sebagai bentuk penghargaan untuk pemanfaatan dana tersebut oleh BMT Mu'allimin.

4) Umroh VVIP

Simpanan umroh VVIP merupakan simpanan titipan berupa tabungan melalui akad wadiah yaddhamanah. Setoran perbulan untuk simpanan umroh VVIP adalah Rp. 1.500.000,-. $\quad$ Adapun penyetorannya dilakukan dalam batas waktu selama 24 bulan. Dalam simpanan umroh VVIP, BMT Mu'allimin dapat membagi imbalan seperti bonus kepada anggota sebagai bentuk apresiasi atas pemanfaatan dana tersebut oleh BMT Mu'allimin. Adapun perbedaan dari setiap produk simpanan umroh yaitu dilihat dari sisi fasilitas yang disediakan pihak 
BMT Mu'allimin untuk peserta umroh.

2. Produk Pembiayaan

a. Pembiayaan jual beli dan sewa dalam bentuk akad murabahah, istishna, salam, dan ijarah. Dimana pada akad murabahah terdiri dari murabahah barang rumah tangga, murabahah kendaraan dan murabahah barang elektronik. Sedangkan akad istishna disediakan bagi yang berniat membeli rumah. Sedangkan untuk akad salam dan ijarah disediakan untuk kendaraan dan juga KPR.

b. Pembiayaan modal kerja dalam bentuk akad mudharabah dan musyarakah.

c. Pembiayaan gadai emas dalam bentuk akad rahn emas dan rahn BPKB.

d. Pembiayaan non komersial yaitu pembiayaan yang diadakan bagi pelajar, mahasiswa dan dhuafa yang pengembaliannya sesuai atau tetap dengan pembiayaan yang disepakati ketika awal akad.

3. Layanan Jasa

a. Electronic Delivery Channel (EDC)

EDC merupakan fasilitas pelayanan yang diberikan BMT Mu'allimin kepada nasabah agar merasa mudah dan aman ketika bertransaksi. Dari seluruh BMT yang hadir di Indonesia, BMT Mu'allimin merupakan BMT satu-satunya yang memiliki layanan EDC.

b. SMS Banking

SMS Banking merupakan layanan yang difasilitasi BMT Mu'allimin bagi nasabah agar merasa aman dan percaya dalam bertransaksi karena dapat memperoleh informasi terkait saldo nasabah sesudah bertransaksi. Dari seluruh BMT Indonesia, BMT Mu'allimin merupakan BMT pertama yang memiliki layanan SMS Banking.

Dalam jangka pendek BMT Mu'allimin akan meluncurkan layanan terbaru yaitu semacam aplikasi mobile banking, hal tersebut dilakukan untuk memfasilitasi kemudahan bagi nasabah BMT Mu'allimin dalam bertransaksi.

\section{Karakteristik Responden}

Responden dari penelitian ilmiah ini ialah nasabah BMT Mu'allimin yang dijadikan sampel dan ditentukan melalui teknik simple random sampling, dimana nasabah BMT Mu'allimin dipilih satupersatu secara acak sehingga mempunyai kesempatan yang setara untuk dijadikan sampel, jika nasabah yang sudah terpilih, maka tidak dipilih lagi. Adapun karakteristik dari responden diketahui berdasarkan kategori jenis pekerjaan, usia, pendapatan serta jenis kelamin.

Sesuai dengan perolehan data diolah dari 128 responden yaitu nasabah BMT Mu'allimin dengan perolehan data melalui penyebaran kuesioner, secara lebih rincinya yaitu dari 128 responden BMT Mu'allimin laki-lakinya terdapat sebanyak 73 orang (58\%) dan perempuan ada 55 orang (42\%). Perbedaan total laki-laki dalam hasil perhitungan tersebut lebih mendominasi dibanding perempuan, yaitu sesuai dengan pengambilan data pada waktu penelitian, sehingga rata-rata nasabah BMT Mu'allimin sebanyak 128 responden yang diteliti secara acak mayoritas responden atau nasabah BMT Mu'allimin ialah laki-laki.

Usia dari 128 nasabah BMT Mu'allimin yang dijadikan responden diketahui yaitu yang dibawah usia 20 tahun terdapat sebanyak 25 orang (20\%), usia dari 20 hingga 30 tahun totalnya 72 orang (56\%), dan usia yang diatas 30 tahun sejumlah 31 orang (24\%). Sehingga dari perolehan data tersebut penulis dapat memberikan deskripsi tentang karakteristik responden BMT Mu'allimin berdasarkan usia, dimana hasil penelitiannya yang mendominasi adalah usia 20 hingga 30 tahun dengan persentase (56\%). Sedangkan usia 20 tahun kurang merupakan yang paling minim dengan bagian sebesar (20\%). Responden yang mendominasi adalah yang berusia 20 hingga 30 tahun sebab di usia tersebut merupakan usia produktif. 
Jenis pekerjaan dari 128 nasabah BMT Mu'allimin, terdapat 1 orang yang berjenis pekerjaan sebagai PNS, 61 orang responden bekerja sebagai wiraswasta, 35 responden berprofesi menjadi mahasiswa/pelajar dan sejumlah 31 responden melakukan pekerjaan lainnya. Pekerjaan responden yang memilih pekerjaan lainnya yaitu responden yang pekerjaannya menjadi ibu rumah tangga, guru yang masih berstatus honorer dan profesi lainnya. Nasabah berjenis pekerjaan wiraswasta lebih mendominasi dibanding jenis pekerjaan sebagai PNS, mahasiswa/pelajar dan pekerjaan lainnya.

Berdasarkan tingkat pendapatan, dari 128 responden yang jadi nasabah BMT Mu'allimin, terdapat 37 responden memiliki penghasilan kurang dari Rp. $1.000 .000,-, 40$ orang responden memiliki penerimaan diatas Rp. 1.000.000,-, 36 responden memiliki penghasilan Rp. 2.000.000 - Rp. 3.000.000,- dan responden sebanyak 15 memiliki pemasukan diatas Rp. 3.000.000,-. Pendapatan dominan dari responden yang mendapatkan gaji di atas Rp. 1.000.000,- dengan persentase (31\%) setara dengan perolehan data dari penelitian yaitu nasabah dengan pemasukan diatas Rp. 1.000.000,didominasi oleh wiraswasta.

\section{Uji Reliabilitas dan Uji Validitas}

Uji reliabilitas dalam karya ilmiah ini dilaksanakan dengan meninjau nilai yang dihasilkan pada koefisien Cronbach Alpha yang juga diuraikan sebagai hubungan positif dari tiap pernyataan atas pernyataan lainnya. Suatu alat penelitian disebut reliabel apabila mempunyai nilai Alpha berkisar antara 0,60 sampai 0,70. Dasar pengambilan keputusan adalah (Yvonne dan Robert, 2013) :

Jika Cronbach Alpha $>0,60 \rightarrow$ construct reliable

Jika Cronbach Alpha $<0,60 \rightarrow$ construct not reliable

Hasil pengujian reliabilitas membuktikan bahwa perolehan nilai statistik adalah sebesar 0,883. Nilai tersebut menerangkan bahwa untuk pengajuan 17 pernyataan pada nasabah sebagai responden adalah reliabel, karena sesuai asas pengambilan keputusan bahwa $0,883>0,60$. Untuk uji validitas ditentukan berdasarkan koefisien korelasi (r), dimana jika $r_{\text {hitung }}>r_{\text {tabel }}$, maka instrumen tes yang diujicobakan tersebut dapat dinyatakan valid.

Tingkat validitas diketahui dalam tabel pada bagian Corrected Item-Total Correlation yang memberikan petunjuk keadaan korelasi tiap skor item (nilai

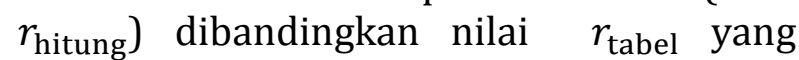
dihasilkan melalui program SPSS type 22. Dengan menggunakan distribusi tabel $r$ berdasarkan $\alpha=0,05$ telah didapat $r_{\text {tabel }}=$ 0,159 . Sesuai dengan perolehan data menunjukkan nilai validitas dari pernyataan nomor 1 (IP1) sampai dengan pernyataan nomor 17 (KN6) berada di atas 0,159 . Sehingga semua pernyataan yang dimanfaatkan dinyatakan valid.

Selanjutnya adalah hasil dari perolehan data tentang tanggapan responden dalam menarik nasabah membuka tabungan di BMT melalui inovasi layanan atau inovasi produk dengan melalui proses analisis skala likert, secara lebih rinci terdeskripsikan dalam paragraf berikut ini.

Tanggapan responden terkait pernyataan produk/jenis layanan BMT Mu'allimin sangat memiliki manfaat untuk nasabah, yang beranggapan sangat setuju totalnya yaitu 33 responden dengan pembagian $(30,28 \%)$ dan beranggapan setuju berjumlah 95 orang dengan bagian $(69,72 \%)$. Hasil perhitungan skala likert diperoleh angka kriteria penafsiran sebesar $\mathrm{M}=4,26$. Dari perolehan data tersebut memperlihatkan rata-rata beranggapan "setuju" dengan produk / jenis layanan BMT Mu'allimin yang amat bermanfaat bagi nasabah.

Respon nasabah terkait pernyataan produk/jenis layanan yang dimiliki BMT Mu'allimin sesuai kebutuhan nasabah, yaitu sangat setuju berjumlah 26 responden dengan bagian $(24,34 \%)$, setuju 98 responden dengan pembagian $(73,41 \%)$, 
dan responden kurang setuju berjumlah 12 dengan bagian $(2,25 \%)$. Hasil perhitungan skala likert diperoleh angka kriteria penafsiran sebesar $M=4,17$. Dari perolehan data tersebut menegaskan rata-rata responden "setuju" dengan produk/jenis layanan yang disediakan BMT Mu'allimin sesuai kebutuhan nasabah.

Pendapat responden terkait pernyataan produk/jenis layanan baru yang dipromosikan BMT Mu'allimin berbeda dengan BMT lain, yaitu sangat setuju terdapat 22 responden dengan persentase $(21,15 \%)$, setuju 92 responden dengan bagian (70,77\%), kurang setuju 13 responden dengan pembagian $(7,5 \%)$, tidak setuju jumlahnya 1 orang dengan persentase $(0,39 \%)$ dan total responden sangat tak setuju berjumlah 1 responden persentasenya $(0,19 \%)$. Hasil perhitungan skala likert diperoleh angka kriteria penafsiran sebesar M=4,06. Hasil pemaparan di atas menerangkan rata-rata nasabah "setuju" dengan produk/jenis layanan baru yang dikeluarkan BMT Mu'allimin berlainan dengan yang diluncurkan oleh BMT lain.

Tanggapan responden terkait pernyataan produk/jenis layanan di BMT Mu'allimin lebih unggul dari pada produk di BMT lainnya, yang beranggapan sangat setuju berjumlah 14 responden dengan persentase $(13,75 \%)$, setuju 97 responden persentasenya $(76,23 \%)$, dan yang kurang setuju 17 responden persentasenya adalah $(10,02 \%)$. Hasil perhitungan skala likert diperoleh angka kriteria penafsiran sebesar $M=3,98$. Hasil pengolahan data skala likert menunjukkan bahwa umumnya responden "setuju" dengan produk/jenis layanan di BMT Mu'allimin lebih unggul dibanding produk BMT lainnya.

Respon nasabah terkait pernyataan BMT Mu'allimin memiliki produk dan jenis layanan sesuai perkembangan zaman, yang merespon sangat setuju berjumlah 27 responden $(25,14 \%)$, setuju 99 responden $(73,74 \%)$, dan yang kurang setuju 2 responden persentasenya adalah $(1,12 \%)$. Hasil perhitungan skala likert diperoleh angka kriteria penafsiran sebesar $M=4,20$. Hasil tersebut menegaskan bahwa rata-rata beranggapan "setuju" dengan BMT Mu'allimin yang mempunyai produk dan jenis layanan telah mengikuti perkembangan zaman.

Pendapat responden terkait pernyataan BMT Mu'allimin merupakan BMT pertama yang memiliki pelayanan mesin EDC dan SMS banking, yaitu sangat setuju berjumlah 40 responden $(37,17 \%)$, setuju 77 responden (57,25\%), kurang setuju 8 responden $(4,46 \%)$, dan 3 orang tidak setuju $(1,12 \%)$. Hasil perhitungan skala likert diperoleh angka kriteria penafsiran sebesar $\mathrm{M}=4,20$. Hasil perhitungan tersebut mendeskripsikan rata-rata responden "setuju" dengan BMT Mu'allimin sebagai BMT pertama yang memiliki pelayanan SMS banking atau mesin EDC.

Tanggapan responden terkait pernyataan adanya SMS Banking serta EDC membuat saya tertarik menjadi nasabah BMT Mu'allimin, persentase yang beranggapan sangat setuju berjumlah 28 responden $(26,62 \%)$, persentase setuju 87 responden $(66,16 \%)$, kurang setuju 12 responden (6,84\%), dan tanggapan 1 responden tidak setuju (0,19\%). Hasil perhitungan skala likert diperoleh angka kriteria penafsiran sebesar $M=4,11$. Dari keterangan di atas menggambarkan ratarata nasabah "setuju" dengan adanya mesin EDC atau SMS Banking membuat responden tertarik menjadi nasabah BMT Mu'allimin.

Respon nasabah terkait pernyataan saya memilih menyimpan tabungan di BMT Mu'allimin alasannya adalah karena ada mesin EDC dan SMS Banking, yaitu persentase sangat setuju berjumlah 25 responden $(24,61 \%)$, setuju 78 responden (61,42\%), kurang setuju 22 responden $(12,99 \%), 2$ orang tidak setuju $(0,79 \%)$, dan persentase anggapan 1 responden paling tidak setuju $(0,1 \%)$. Hasil perhitungan skala likert diperoleh angka kriteria penafsiran sebesar $M=3,97$. Dari hasil perhitungannya memperlihatkan 
bahwa umumnya responden "setuju" dengan anggapan memilih menyimpan di BMT Mu'allimin satu dari beberapa alasan ialah karena keberadaan fasilitas EDC serta SMS Banking.

Tanggapan responden terkait pernyataan saya percaya menyimpan simpanan pada BMT Mu'allimin karena adanya mesin EDC dan SMS Banking, persentase beranggapan sangat setuju berjumlah 24 responden $(23,21 \%), 88$ orang setuju $(68,09 \%), 14$ responden kurang setuju (8,12\%), tanggapan 1 responden tidak setuju $(0,39 \%)$, dan tanggapan 1 responden yang lain amat tidak setuju besaran persentasenya $(0,19 \%)$. Hasil perhitungan skala likert diperoleh angka kriteria penafsiran sebesar $\mathrm{M}=4,04$. Hasil perhitungannya memberikan gambaran mengenai rata-rata responden "setuju" bahwa responden percaya menyimpan pada BMT Mu'allimin karena adanya SMS Banking serta EDC.

Respon nasabah terkait pernyataan saya merasa aman memiliki simpanan di BMT Mu'allimin karena adanya mesin EDC dan SMS Banking, yang merespon sangat setuju persentasenya berjumlah 32 (29,58\%), 93 orang setuju $(68,76 \%)$ dan yang kurang setuju berjumlah 3 responden (1,66\%). Hasil perhitungan skala likert diperoleh angka kriteria penafsiran sebesar $\mathrm{M}=4,31$. Hasil tersebut membuktikan bahwa umumnya nasabah "setuju" mengenai anggapan nasabah merasa aman simpan uang di BMT Mu'allimin karena adanya layanan tersebut.

Pendapat responden terkait pernyataan informasi tabungan nasabah selalu update karena adanya mesin EDC atau SMS Banking, persentase yang berpendapat sangat setuju berjumlah 36 responden $(32,97 \%), 90$ responden $(65,93 \%)$ persentase tanggapan setuju dan yang kurang setuju totalnya yaitu 2 responden $(1,1 \%)$. Hasil perhitungan skala likert diperoleh angka kriteria penafsiran sebesar $M=4,27$. Hasil perhitungan tersebut memperlihatkan rata-rata responden "setuju" bahwa informasi tabungan nasabah selalu update karena adanya mesin EDC atau SMS Banking.

Tanggapan responden terkait pernyataan saya memutuskan menggunakan produk serta layanan jasa BMT Mu'allimin karena sesuai keperluan saya, persentase yang beranggapan sangat setuju berjumlah 35 responden $(32,23 \%)$, setuju 89 responden $(65,56 \%)$, dan yang kurang setuju totalnya 4 responden (2,21\%). Hasil perhitungan skala likert menjelaskan angka kriteria penafsiran sebesar $M=4,24$. Hasil perhitungan skala likert menegaskan rata-rata responden "setuju" bahwa responden memutuskan menggunakan layanan dan produk jasa BMT Mu'allimin karena sesuai yang diperlukan nasabah.

Respon nasabah terkait pernyataan apa yang nasabah peroleh setelah menanam simpanan di BMT Mu'allimin, sesuai dengan harapan, persentase yang merespon sangat setuju berjumlah 29 responden $(27,05 \%)$, setuju 94 responden $(70,15 \%)$, dan persentase 5 responden untuk total yang kurang setuju $(2,8 \%)$. Hasil perhitungan skala likert diperoleh angka kriteria penafsiran sebesar $M=4,19$. Dari angka di atas menegaskan rata-rata beranggapan "setuju" dengan apa yang nasabah peroleh setelah mengumpulkan dana di BMT Mu'allimin, sesuai harapan.

Pendapat responden terkait pernyataan jika saya memiliki uang lebih, saya ingin menyimpannya di BMT Mu'allimin, persentase yang berpendapat sangat setuju berjumlah 36 responden $(33,33 \%)$, setuju 84 responden $(62,22 \%)$, dan beranggapan tidak setuju 8 responden (4,45\%). Hasil perhitungan skala likert diperoleh angka kriteria penafsiran sebesar $M=4,22$. Dari informasi di atas menegaskan rata-rata responden "setuju" bahwa jika nasabah memiliki uang lebih, nasabah ingin menyimpannya di BMT Mu'allimin. Menurut hasil wawancara mengenai tanggapan di atas yaitu sebab produk yang disediakan BMT Mu'allimin sangat bervariasi, cukup banyak perbedaan 
dengan BMT pada umunya serta membuat nasabah tertarik.

Tanggapan responden terkait pernyataan saya ingin terus menyisihkan tabungan di BMT Mu'allimin, persentase beranggapan sangat setuju berjumlah 23 responden (21,95\%), setuju 96 responden $(73,28 \%), 7$ responden kurang setuju $(4,01 \%)$ dan total persentase yang tidak setuju sebanyak 2 responden $(0,76 \%)$. Hasil perhitungan skala likert diperoleh angka kriteria penafsiran sebesar $M=4,09$. Dari hasil di atas menerangkan rata-rata responden "setuju" bahwa nasabah ingin terus menyimpan tabungan di BMT Mu'allimin.

Pendapat responden terkait pernyataan saya memilih BMT Mu'allimin karena pelayanannya dapat dilakukan dimana saja dengan pelayanan jemput bola, persentase yang berpendapat sangat setuju berjumlah 59 responden (51,94\%), 68 orang setuju $(47,89 \%)$ dan total 1 responden paling tidak setuju $(0,17 \%)$. Hasil perhitungan skala likert diperoleh angka kriteria penafsiran sebesar $M=4,44$. Hasil perhitungannya memperlihatkan rata-rata responden "setuju" bahwa responden memilih BMT Mu'allimin karena pelayanannya dapat dilakukan dimanapun menggunakan jemput bola.

Respon nasabah terkait pernyataan saya memilih mengamankan dana di BMT Mu'allimin karena jumlah setorannya dapat saya jangkau, persentase yang merespon sangat setuju berjumlah 53 responden $(47,07 \%)$, setuju 74 responden $(52,57 \%)$ dan tanggapan 1 responden tidak setuju $(0,36 \%)$. Hasil perhitungan skala likert diperoleh angka kriteria penafsiran sebesar $M=4,4$. Dari hasil perhitungannya menegaskan rata-rata nasabah "setuju" bahwa responden memilih mengamankan uang di BMT Mu'allimin karena jumlah setorannya dapat dijangkau.

\section{Inovasi Produk dan Layanan BMT Mu'allimin}

Berdasarkan perolehan data penelitian dari kuesioner dan wawancara, inovasi produk yang dilakukan BMT
Mu'allimin diantaranya adalah simpanan rihlah, simpanan umroh yang dibuat berdasarkan kelas dan beberapa produk pembiayaan yang tentunya tidak ditemukan di BMT lain. Sedangkan inovasi layanan yang diluncurkan BMT Mu'allimin ialah aplikasi SMS Banking serta EDC. Kemudian BMT Mu'allimin juga melakukan inovasi dari sisi bagi hasil lebih dominan dari setiap produk simpanan dibanding bagi hasil BMT lain. Serta BMT Mu'allimin juga memudahkan nasabah dengan jumlah setoran yang dapat dijangkau dibanding lembaga keuangan lain. Berdasarkan indikator yang dijelaskan oleh Ferrell, inovasi layanan dan produk yang diadakan oleh BMT Mu'allimin termasuk ke dalam produk baru (me too product), yaitu produk yang dikeluarkan merupakan produk baru untuk perusahaan namun tidak baru untuk pasar. Kemudian hal baru bagi pasar dari produk serta layanan yang diluncurkan BMT Mu'allimin ialah penamaan dan sistemnya. Dimana hal tersebut merupakan inovasi dari sisi atribut produk termasuk juga kategori desain produk dalam hal jasa.

Data yang diambil melalui instrumen berupa pernyataan sebanyak 17 butir dalam bentuk lima skala dengan skor urutan dari mulai satu hingga lima, dimana skor lima adalah yang tertinggi, kemudian dianalisa dan dikelompokkan menggunakan distribusi frekuensi relatif dalam rangka untuk memudahkan membaca data secara tepat berkaitan dengan peran inovasi produk serta inovasi layanan dalam meningkatkan ketertarikan nasabah membuka rekening tabungan di BMT Mu'allimin.

Berdasarkan analisis data distribusi frekuensi relatif didapatkan 0,74 (74\%) responden setuju, 0,26 (26\%) sangat setuju, kurang setuju (0\%), tidak setuju $(0 \%)$, sangat tidak setuju $(0 \%)$. Sehingga terlihat kebanyakan responden setuju bahwa layanan dan produk BMT Mu'allimin bermanfaat untuk nasabah dengan persentase $74 \%$. Sesuai hasil wawancara, produk yang bermanfaat untuk sekarang ini bagi nasabah sebagian besar yaitu 
produk simpanan wadiah dan tabungan pendidikan. Produk simpanan wadiah bermanfaat karena merupakan tabungan dengan sistem setoran dan pengambilan yang bisa dilakukan kapan saja. Sedangkan tabungan pendidikan bermanfaat karena nasabah dapat menyimpan dana secara terpisah sehingga tidak terganggu dengan kepentingan yang lain. Untuk produk layanan nasabah yang paling bermanfaat adalah pelayanan dengan sistem jemput bola, karena nasabah yang bertransaksi setoran atau penarikan pihak BMT siap melayani dimanapun, sehingga amat efektif serta memudahkan. Selain itu nasabah juga merasa diuntungkan dan merasa aman karena dengan keberadaan BMT Mu'allimin bisa lebih tertata dalam mengatur keuangan, dan juga tawaran pembagian hasil dari BMT Mu'allimin lebih menjanjikan dari lembaga keuangan lain.

Selanjutnya dihasilkan 0,03 (3\%) responden kurang setuju, 0,77 (77\%) setuju, sangat setuju $0,20(20 \%)$, sangat tidak setuju (0\%) dan (0\%) tidak setuju. Sehingga disimpulkan responden setuju bahwa layanan atau produk BMT Mu'allimin sesuai dengan yang nasabah butuhkan sebesar 77\%. Sesuai hasil wawancara, secara keseluruhan produk/jenis layanan yang diadakan oleh BMT Mu'allimin telah seimbang dengan yang nasabah butuhkan, namun yang paling diperlukan nasabah dominan saat ini yaitu produk simpanan wadiah, tabungan pendidikan, produk pembiayaan modal untuk usaha dan layanan melalui sistem bola, karena nasabah merasakan manfaatnya sinkron dengan yang dibutuhkan, khususnya nasabah yang beprofesi sebagai wirausaha.

Berdasarkan analisis data diperoleh $0,17(17 \%)$ responden sangat setuju, 0,71 (71\%) setuju, kurang setuju 0,10 (10\%), tidak setuju $0,01(1 \%)$, sangat tidak setuju $0,01(1 \%)$. Data tersebut terlihat jelas responden setuju bahwa layanan produk baru BMT Mu'allimin berbeda dengan BMT lain dengan persentase $71 \%$. Sesuai hasil wawancara bahwa perbedaan produk BMT
Mu'allimin yang paling dominan adalah produk simpanan rihlah, simpanan umrah, produk pembiayaan secara keseluruhan dan pelayanan EDC serta SMS Banking. Perbedaan secara spesifik dari produk pembiayaan adalah proses pencairan pengajuan pembiayaan relatif cepat, sederhana dan mudah serta bagi hasilnya untuk nasabah lebih banyak.

Berdasarkan analisis data didapatkan 0,76 (76\%) nasabah setuju, 0,11 (11\%) sangat setuju, kurang setuju 0,13 (13\%), (0\%) tidak setuju dan (0\%) sangat tidak setuju. Data tersebut menunjukan bahwa nasabah setuju dengan layanan atau produk BMT Mu'allimin lebih unggul dari BMT lain dengan bagian sebesar 76\%. Menurut hasil wawancara, produk/jenis layanan BMT Mu'allimin lebih unggul karena produk yang diadakan BMT Mu'allimin lebih bervariasi, baik produk simpanan atau produk pembiayaannya. Sedangkan untuk layanan yang menjadikan BMT Mu'allimin lebih unggul dari pada BMT lain adalah keberadaan mesin EDC atau SMS Banking, karena adanya fasilitas tersebut kualitas rasa percaya dan perasaan aman nasabah menjadi meningkat. Selain itu, adanya pembagian hasil untuk nasabah lebih jelas dan lebih besar.

Sesuai hasil analisis didapatkan 0,77 (77\%) responden setuju, 0,21 (21\%) sangat setuju, kurang setuju 0,02 (2\%), $(0 \%)$ sangat tidak setuju dan $(0 \%)$ tidak setuju. Data di atas menegaskan bahwa responden setuju BMT Mu'allimin memiliki produk dan juga layanan sesuai perkembangan zaman dengan persentase 77\%. Sesuai informasi hasil wawancara, secara teknologi, layanan EDC atau SMS Banking yang menjadi fasilitas BMT Mu'allimin telah mengikuti perkembangan zaman, terlebih lagi jika BMT Mu'allimin dapat meluncurkan aplikasi Mobile Banking for Android seperti yang dimiliki LKB pada umumnya. Hal lainnya yaitu BMT Mu'allimin telah menyedikan layanan jasa pemesanan dan pembayaran seperti pemesanan tiket pesawat, tiket kereta api, 
voucher hotel, dan pembayaran angsuran, serta fasilitas lainnya.

Berdasarkan analisis diperoleh 0,60 (60\%) responden setuju, 0,31 (31\%) sangat setuju, kurang setuju 0,06 (6\%), (0\%) tidak setuju 0,03 (3\%) dan (0\%) sangat tidak setuju. Responden setuju bahwa BMT Mu'allimin merupakan BMT pertama yang memiliki layanan EDC serta SMS Banking dengan persentase $60 \%$. Karena sesuai dengan data yang diterima dari banyaknya responden yang diwawancara bahwa BMT Mu'allimin merupakan BMT pertama yang mempunyai fasilitas tersebut dibanding dengan BMT sebelumnya yang pernah bermitra dengan mereka, serta responden yang lainnya baru mengetahui dari BMT Mu'allimin bahwa lembaga keuangan berbentuk BMT juga ada fasilitas tersebut.

Dihasilkan dari analisis data 0,09 (9\%) responden kurang setuju, 0,68 (68\%) setuju, sangat setuju $0,22(22 \%)$, sangat tidak setuju 0,01 (1\%) dan (0\%) tidak setuju. Sehingga disimpulkan responden setuju bahwa keberadaan EDC/SMS Banking memebuat nasabah tertarik menjadi nasabah BMT Mu'allimin sebesar $68 \%$. Hasil wawancara terkait tanggapan tersebut yaitu disebabkan adanya fasilitas EDC dan fasilitas SMS Banking dapat memberikan laporan secara update mengenai saldo tabungan nasabah ketika bertransaksi baik penarikan atau penyetoran.

Sesuai analisis data diperoleh 0,19 (19\%) responden sangat setuju, 0,61 (61\%) setuju, kurang setuju 0,17 (17\%), tidak setuju 0,02 (2\%), sangat tidak setuju 0,01 (1\%). Perhitungan data tersebut terlihat jelas bahwa responden setuju atas pernyataan salah satu alasan nasabah membuka tabungan di BMT Mu'allimin karena ada aplikasi layanan mesin EDC atau SMS Banking dengan persentase 61\%. Sesuai keterangan wawancara mengenai tanggapan tersebut ialah karena keberadaan fasilitas tersebut lebih menuruti perkembangan zaman dibanding BMT yang lain.
Didapatkan hasil analisis 0,69 (69\%) nasabah setuju, 0,19 (19\%) sangat setuju, kurang setuju 0,10 (10\%), 0,01 (1\%) tidak setuju dan $0,01(1 \%)$ sangat tidak setuju. Angka tersebut memperlihatkan bahwa kepercayaan nasabah dalam menabung didasarkan atas adanya mesin EDC dan juga SMS Banking dengan bagian sebesar 69\%. Hasil wawancara menunjukkan bahwa dengan adanya fasilitas layanan tersebut yang menjadikan nasabah percaya menyimpan tabungan di BMT Mu'allimin karena laporan saldo yang masuk kepada nasabah saat bertransaksi baik penarikan atau setoran tidak keliru dengan perhitungan nasabah serta setara dengan yang dicantumkan di buku tabungan.

Diperoleh hasil analisis 0,73 (73\%) responden setuju, 0,25 (25\%) sangat setuju, kurang setuju 0,02 (2\%), (0\%) tidak setuju dan juga sangat tidak setuju (0\%). Data tersebut menjelaskan bahwa rasa aman nasabah timbul karena ada layanan EDC atau SMS Banking dengan persentase 73\%. Keterangan ketika wawancara mengenai tanggapan di atas yaitu karena laporan yang dikirim oleh pihak BMT Mu'allimin melalui pelayanan SMS Bnking dan EDC tersebut diterima secara langsung serta personal oleh nasabah sehingga dapat tetap dikontrol tanpa mendatangi BMT. Selain itu keberadaan SMS Banking serta mesin EDC, terjadinya kesalahan dari pihak internal atau eksternal sangat kecil, karena itu nasabah merasa aman.

Berdasarkan analisis data didapatkan 0,70 (70\%) responden setuju, 0,28 (28\%) sangat setuju, kurang setuju 0,02 (2\%), tidak setuju (0\%), sangat tidak setuju (0\%). Sehingga dominasi responden setuju informasi tabungan nasabah selalu update karena ada SMS bankin dan EDC dengan persentase $70 \%$. Hasil wawancara menunjukkan bahwa informasi update saldo yang disampaikan melalui layanan EDC dan SMS Banking mampu menolong nasabah agar bisa mengontrol tabungan mereka dan juga menjadi point lebih bagi nasabah BMT Mu'allimin supaya mampu berkompetisi dengan BMT yang lain 
sehingga mampu menarik nasabah lebih banyak.

Sesuai hasil analisis $0,03 \quad(3 \%)$ responden kurang setuju, 0,70 (70\%) setuju, sangat setuju 0,28 (28\%), sangat tidak setuju (0\%) dan (0\%) tidak setuju. Sehingga disimpulkan bahwa kebutuhan nasabah adalah satu dari berbagai faktor yang menjadikan nasabah membuka rekening tabungan di BMT Mu'allimin sebesar 70\%. Berdasarkan hasil wawancara, nasabah yang mempunyai simpanan di BMT Mu'allimin telah memilih produk tabungan sesuai kebutuhan mereka, dan untuk sekarang ini produk tabungan yang banyak diperlukan oleh nasabah yaitu produk simpanan wadiah dan tabungan pendidikan.

Dihasilkan data 0,23 responden sangat setuju, $0,73 \quad(73 \%)$ setuju, kurang setuju 0,04 (4\%), sangat tidak setuju (0\%), tidak setuju (0\%). Sesuai data tersebut terlihat jelas bahwa apa yang nasabah peroleh dengan yang diharapakan telah sesuai sebesar 73\%. Dalam hasil wawancara disebutkan bahwa bagi hasil yang didapat nasabah telah sesuai yaitu lebih bagus dari BMT lain, uang yang ditabungkan ke BMT Mu'allimin terasa lebih berkah dibanding disimpan di bank lain dan juga selalu dimudahkan dengan pelayanan dari pihak BMT Mu'allimin.

Sesuai dengan analisis data diperoleh $0,28(28 \%)$ responden sangat setuju, 0,66 (66\%) setuju, kurang setuju 0,06 (6\%), (0\%) tidak setuju dan $(0 \%)$ sangat tidak setuju. Terlihat jelas dari nilai di atas bahwa responden setuju terkait keinginan nasabah menyimpan uang di BMT Mu'allimin apabila memiliki uang lebih dengan bagian terbanyak 66\%. Menurut hasil wawancara mengenai tanggapan di atas yaitu sebab produk yang disediakan BMT Mu'allimin sangat bervariasi, cukup banyak perbedaan dengan BMT pada umunya serta membuat nasabah tertarik.

Diperoleh hasil analisis data 0,75 (75\%) responden setuju, 0,18 (18\%) sangat setuju, kurang setuju 0,05 (5\%), tidak setuju 0,02 (2\%) dan (0\%) sangat tidak setuju. Data tersebut menegaskan bahwa anggapan setuju mendominasi berkenaan dengan pernyataan nasabah ingin terus menerus menabung di BMT Mu'allimin dengan persentase $75 \%$. Nasabah sudah percaya dan merasa dimudahkan oleh pihak BMT Mu'allimin. Selain itu, pada saat wawancara disebutkan bahwa dengan sistemnya yang sesuai syariah, membuat nasabah ingin terus menyimpan dana di BMT Mu'allimin agar dapat memperoleh keberkahan.

Berdasarkan analisis data didapatkan 0,53 (53\%) nasabah setuju, 0,46 (46\%) sangat setuju, kurang setuju (0\%), (0\%) tidak setuju dan $0,01(1 \%)$ sangat tidak setuju. Data tersebut menunjukkan dominasi responden setuju bahwa nasabah memilih membuka tabungan di BMT Mu'allimin karena transaksi dapat dilakukan dimana saja melalui metode jemput bola dengan persentase 53\%. Dari data hasil wawancara, pelayanan dengan cara jemput bola adalah satu dari beberapa sebab yang membuat nasabah ingin membuka rekening di BMT Mu'allimin karena pelayanan tersebut memudahkan nasabah sehingga tidak menyita waktu lama dibanding datang dan mengantri menabung langsung ditempatnya.

Hasil perhitungan data didapatkan 0,58 (58\%) responden setuju, 0,41 (41\%) sangat setuju, kurang setuju (0\%), (0\%) sangat tidak setuju, tidak setuju 0,01 (0\%). Perhitungan di atas menegaskan bahwa responden setuju jumlah yang disetor kepada BMT Mu'allimin dapat dijangkau dengan persentase 58\%. Sesuai hasil wawancara, di BMT Mu'allimin nasabah dapat menabung dengan jumlah uang dibawah Rp. 50.000,-. Sehingga dengan keberadaan BMT Mu'allimin nasabah yang masih berpenghasilan rendah dapat tetap menabung di Institusi Keuangan dengan rasa aman.

\section{Peran Inovasi Produk dan Layanan dalam Meningkatkan Daya Tarik Nasabah}

Hasil kuesioner dan juga wawancara telah menentukan kesimpulan bahwa 
inovasi produk dan juga inovasi layanan yang dilakukan BMT Mu'allimin cukup berperan dalam memicu dan meningkatkan ketertarikan nasabah untuk menabung. Hal tersebut dipertegas oleh persentase jawaban responden dari nilai hasil kuesioner menunjukkan bahwa sebagian banyak memberi jawaban setuju 74\% mengenai manfaat layanan dan produk BMT Mu'allimin, dominasi menjawab setuju 77\% terkait kesesuaian layanan atau produk BMT Mu'allimin dengan kebutuhan nasabah, respon paling dominan setuju 71\% berkaitan dengan layanan serta produk baru BMT Mu'allimin berbeda dengan BMT lain, paling banyak setuju $76 \%$ perihal layanan dan produk BMT Mu'allimin lebih unggul dibanding BMT lain, jawaban setuju mendominasi $77 \%$ berkenaan layanan atau produknya sesuai perkembangan zaman, jawaban setuju didominasi sebesar $60 \%$ tentang BMT Mu'allimin adalah yang pertama memiliki layanan EDC dan juga SMS Banking, 68\% setuju bahwa keberadaan mesin EDC dan SMS Banking yang menjadikan mereka tertarik untuk menabung, 61\% setuju dengan alasan mereka simpan dana di BMT Mu'allimin salah satunya karena ada layanan EDC, sebagian besar memberi jawaban setuju $69 \%$ mengenai kepercayaan nasabah menabung didasarkan karena adanya EDC serta SMS Banking, dominasi menjawab setuju $73 \%$ terkait rasa aman untuk menabung karena ada SMS Banking, respon paling dominan setuju $70 \%$ berkaitan dengan informasi tabungan nasabah selalu update karena layanan EDC/SMS Banking, paling banyak setuju 70\% perihal keputusan nasabah membuka tabungan karena sesuai kebutuhan, jawaban setuju mendominasi 73\% berkenaan dengan kesesuaian antara perolehan nasabah dengan yang diharapkannya, sebagian besar memberi jawaban setuju 66\% mengenai keinginan nasabah menyimpan uang di BMT Mu'allimin apabila memiliki uang lebih, dominasi menjawab setuju $75 \%$ terkait dengan pernyataan nasabah ingin terus menerus menabung di BMT Mu'allimin, jawaban setuju didominasi sebesar 53\% tentang pelayanannya dapat dilakukan dimana saja melalui sistem jemput bola, 58\% setuju bahwa jumlah setoran di BMT Mu'allimin dapat dijangkau semua kalangan. Namun hasil wawancara menegaskan bahwa dalam hal meningkatkan ketertarikan nasabah membuka rekening di BMT Mu'allimin yang paling memiliki peran adalah produk layanan berupa mesin EDC serta SMS Banking. Sehingga daya tarik nasabah meningkat bukan hanya dikarenakan oleh inovasi produk dan juga inovasi layanan tetapi karena layanan dan produk yang dimiliki BMT Mu'allimin secara menyeluruh memang sesuai dan nasabah sangat membutuhkannya baik hasil inovasi ataupun bukan hasil inovasi.

\section{KESIMPULAN DAN IMPLIKASI}

Berdasarkan keseluruhan rangkaian penelitian yang telah selesai dilakukan terkait peran inovasi produk serta inovasi layanan dalam meningkatkan ketertarikan nasabah menabung di BMT Mu'allimin, maka kesimpulannya yaitu inovasi layanan dan inovasi produk merupakan satu dari banyak faktor yang cukup berperan meningkatkan daya tarik nasabah untuk menabung, terutama inovasi layanan yang dimiliki BMT Mu'allimin yaitu mesin EDC dan SMS Banking. Namun hasil wawancara dan kuesioner menunjukkan bahwa keberhasilan meningkatkan daya tarik nasabah untuk simpan dana di BMT Mu'allimin disebabkan karena kebutuhan nasabah akan layanan dan produk yang sudah disediakan, yang kemudian dilengkapi dengan keberadaan layanan serta produk hasil inovasi.

Terdapat beberapa implikasi pada penelitian ini, implikasinya yaitu adalah:

1. Diharapkan dengan adanya penelitian ini mampu membantu berbagi informasi kepada pihak BMT terkait bagaimana inovasi layanan dan produk mampu memberikan peran dalam meningkatkan daya tarik nasabah untuk menyimpan 
dana di sebuah BMT. Sehingga kelanjutannya setiap BMT mampu untuk terus membuat masyarakat tertarik menjadi nasabah dan simpan dana di BMT.

2. Hasil karya ilmiah ini harapannya dapat dijadikan satu acuan bagi BMT mana saja yang berinovasi produk atau layanan. Sehingga dapat mempertimbangkan bagaimana semestinya membuat inovasi produk dan inovasi layanan agar dapat membuat masayarakat tertarik menjadi nasabah. Dimana hal yang harus diperhatikan ketika membuat inovasi layanan atau produk adalah tidak hanya baru atau berbeda dari yang lain, tetapi harus sesuai dengan yang pasar butuhkan sehingga kelanjutannya dapat menarik nasabah.

\section{DAFTAR PUSTAKA}

Abdullah, Ma'ruf. 2011. Metodologi Penelitian Kuantitatif untuk Ekonomi, Manajemen, Komunikasi dan Ilmu Sosial Lainnya. Yogyakarta: Aswaja Pressindo.

Damayanti, Nurul Farida dan Herianingrum, Sri. Pengaruh Pembiayaan Dana Baitul Maal Wat Tamwil (BMT) Teladan terhadap Kinerja Usaha Mikro di Pasar Semolowaru Surabaya. JESTT, Vol. 1 No. 3.

Daud, Anshar. 2016. Pengaruh Inovasi Layanan dan Keunggulan Posisional Pada Kinerja Pemasaran. Jurnal Siasat Bisnis, Vol 20, No. 1.

Firdausi, Intan. 2016. Pengaruh Inovasi Produk, Daya Tarik Iklan dan Persepsi Harga terhadap Keputusan Pembelian pada Cafe dengan Menu Unik. Skripsi. Yogyakarta: Universitas Negeri Yogyakarta.
Mardikawati, Woro dan Farida, Naili. 2013. Pengaruh Nilai Pelanggan dan Kualitas Layanan Terhadap Loyalitas Pelanggan, Melalui Kepuasan Pelanggan pada Pelanggan Bus Efisiensi (Studi PO Efisiensi Jurusan YogyakartaCilacap). Jurnal Administrasi Bisnis, Volume 2, Nomor 1.

Otoritas Jasa Keuangan. 2015. Statistik Perbankan Indonesia. Diakses dari http://www.bi.go.id/id/statistik/pe rbankan/indonesia/Documents/SPI \%20Agustus\%202015.pdf pada tanggal 09 Januari 2017.

Otoritas Jasa Keuangan. 2016. Statistik Perbankan Indonesia. Diakses dari http://www.bi.go.id/id/statistik/pe rbankan/indonesia/Documents/SPI \%20Agustus\%202015.pdf pada tanggal 19 Maret 2017.

Riduwan dan sunarto. 2014. Pengantar Statistika Pendidikan Sosial, Ekonomi, Komunikasi, dan Bisnis. Bandung: Alfabeta.

Setyawan, Dodiet Aditya. 2013. Distribusi Frekuensi. Surakarta: Poltekes Kemenkes

Sofiah, Neng Siti. 2016. Pengaruh Nisbah Bagi Hasil, Deposito terhadap Loyalitas Nasabah. Jurnal Syarikah: Jurnal Ekonomi Islam, Volume 2, Nomor 2.

Sugiyono. 2013. Metode Penelitian Kombinasi: Mixed Methods. Bandung: Alfabeta.

Swityastuti, Budi dan Sutrisno, Budi. 2014. Manajemen Unit Produksi Berbasis Inovasi Produk (Studi pada SMK Negeri 7 Purworejo). Varia Pendidikan, Vol. 26, No. 2.

Wadah, Rohmatul. 2016. Pengaruh Sistem Manajemen Mutu ISO 9001 : 2008 terhadap Kinerja Amilin di BAZNAS. Jurnal Syarikah: Jurnal Ekonomi Islam, Volume 2, Nomor 1. 